\title{
LEITURA, RECEPÇÃO E CONSTRUÇÕES SIGNIFICANTES EM TEXTOS DE ESCRITORAS NEGRAS
}

\author{
Taise Campos dos Santos Pinheiro de Souza
}

\begin{abstract}
RESUMO
O seguinte trabalho reflete sobre a importância do sujeito leitor na esfera da produção literária, a partir de autores como Jauss (1979), Eagleton (2006), Orlandi (2006), entre outros. Aliando a teoria à análise de textos das escritoras negras, Fátima Trinchão, Jocelia Fonseca, Mel Adún e Rita Santana, observamos como a leitura, por uma perspectiva cultural, significada pelos eixos do gênero e da raça, pode produzir efeitos significativos na construçấo social do sujeito leitor.
\end{abstract}

PALAVRAS-CHAVE: leitura; recepção; escritoras negras.

A atividade de leitura é eminentemente social. (LEENHARDT, 2006, p. 22)

\section{Introdução}

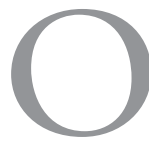

presente artigo é resultado de um projeto de pesquisa de mestrado que se deteve na investigação dos modos de produção, publicação, circulação e recepção de textos de quatro escritoras negras baianas, a saber: Fátima Trinchão ${ }^{1}$, Jocelia

1 Maria de Fátima Conceição Trinchão de Carvalho nasceu em Euclides da Cunha - BA, em 18 de julho de 1959. Formou-se em Letras com Francês pela Universidade Católica de Salvador. Começou a escrever desde a infância em publicaçóes escolares. Publicou em jornais da capital baiana, em especial, no $A T A R D E$. Sua produção bibliográfica, 


\section{Fonseca $^{2}$, Mel Adún $^{3}$ e Rita Santana ${ }^{4}$.}

Aqui, especificamente, fazemos uma análise do impacto da leitura dos textos das escritoras baianas anteriormente citadas para a formação crítica do sujeito leitor. Para tanto, iniciamos com uma revisão da inserção histórica da dimensão receptiva no plano literário, com o surgimento da Estética da Recepção e a introdução do leitor como peça constitutiva da trama literária. Analisamos como a leitura, desenvolvida pela união do teor cultural ao estético, pode potencializar a formação crítica e subjetiva do (a) leitor (a). Por isso, trazemos à cena alguns textos das escritoras pesquisadas, observando como essas mulheres, enquanto donas de seus discursos, tecem sobre si novas enunciações, representaçóes, através da escrita. Ao fazermos leituras interpretativas de textos das escritoras, verificamos como as mesmas, em geral, constroem discursos que se relacionam, direta ou indiretamente, ao seu pertencimento étnico-racial, à sua ancestralidade e às relaçóes de gênero travadas por elas, o que é crucial para o processo de construção subjetiva dos (as) leitores (as), especialmente das mulheres negras.

composta por contos e poemas, dá-se, sobretudo, pela participação em antologias. Os aspectos da vida e obra de Fátima Trincháo evidenciam o comprometimento político-social e cultural da mesma em projetos literários que dignifiquem o ser humano, que rompam com preconceitos e opressóes de minorias estigmatizadas, como as mulheres e o povo negro.

2 A poeta Jocelia Fonseca nasceu em Juazeiro-BA. Reside, desde 1997, em Salvador, onde graduou-se em Letras com inglês. É integrante do grupo baiano "Importuno Poético", formado por três poetisas que realizam apresentaçôes teatralizadas, saraus, declamaçóes, recitais em vários estabelecimentos e instituiçóes baianas. Seu trabalho tem como foco a defesa da alma fêmea, a valorização da estética e força femininas e da cultura afro-brasileira e africana.

3 É escritora, jornalista, roteirista e contadora de histórias. Nasceu em 26 de julho de 1978, em Washington D.C., período da ditadura militar no Brasil, da qual seus pais fugiram. Em 1984, ela chegou ao Brasil, mas retornou para estudar nos Estados Unidos, em 1998. Em 2001, voltou a residir no Brasil, em Salvador, naturalizando-se brasileira e baiana. Integra o coletivo literário Ogum's Toques Negros, o qual, lançando-se à tarefa da editoração, tem se dedicado a publicar e visibilizar textos de autores (as) negros (as). Participa de projetos e iniciativas que se inserem no combate ao racismo e que constituem uma literatura que dá espaço às questóes da cultura africana e negra e às problemáticas ligadas às questóes de gênero.

4 Atriz, poeta e contista, nascida em Ilhéus - BA. É professora da Rede Estadual do município de Lauro de Freitas-BA. É uma figura que, entre tantas produçóes, movimentos e projetos culturais realizados, dá importância crucial à educação e às questóes de gênero. É formada em Letras com Francês. Também é pós-graduada em História Social e Cultura Afro-Brasileira. Seu currículo como atriz é diversificado por atuações no teatro, na televisão e no cinema. 
Assim, partimos dos seguintes questionamentos: $\mathrm{O}$ que os textos das escritoras trazem? Qual a importância de lê-los, recepcioná-los?

Para pensar sobre tais questóes, como já indicamos, nos amparamos na Teoria da recepção, importante corrente de estudos que redimensionou a análise do texto literário a partir da incorporação da dimensão da leitura, da importância da recepção da obra pelo sujeito leitor, como veremos a seguir.

Leitura e recepção entre entrelaces culturais e sociais

Observamos que vários teóricos têm, na atualidade, se debruçado no estudo sobre a participação do (a) leitor (a) no plano da Literatura, entretanto, essa questão nem sempre importou. São diversas as reflexóes que apontam como no passado o texto literário era concebido como um ser com um fim em si próprio, sem considerar o processo de comunicação literária.

Hans Robert Jauss (1979), da Universidade de Constança, na Alemanha, considerado o precursor nos estudos sobre estética da recepção, entre as décadas de 60/70, aponta que, no processo histórico de renovação dos estudos literários e de superação dos impasses da interpretaçáo com um fim em si mesma, foi crucial a formação de uma teoria que abarcasse os processos de produção e recepção, bem como a relação dinâmica entre autor, obra e público.

O referido autor concebe a práxis estética como elemento fundamental de toda arte manifestada como atividade produtora receptiva e comunicativa. Ele também nota como a experiência estética foi, dentro de uma perspectiva histórica, desconsiderada pela Teoria estética e pela Hermenêutica Literária que levavam em conta apenas questóes canônicas, filosóficas com um lugar na tradição e orientadas pela metafísica platônica do belo. E afirma:

[...] a estética se concentrava no papel de apresentação da arte e a história da arte se compreendia como história das obras e de seus autores. Das funçôes vitais da arte, passou-se a considerar apenas o lado produtivo da experiência estética, raramente o receptivo e quase nunca o comunicativo. (JAUSS, 1979, p. 44)

Eagleton (2006), ao tratar sobre a Teoria da recepção, faz uma revisão histórica da concepção de leitura, evidenciando como se fez necessária uma mudança de paradigma em relação à obra literária. Como apontou o autor, a crítica fenomenológica, que influenciou os Formalistas Russos, visava “[...] 
uma leitura totalmente imanente do texto, absolutamente imune a qualquer coisa fora dele" (EAGLETON, 2006, p.90). Dentro dessa acepção, não eram levados em conta: o contexto histórico da obra literária, o (a) autor (a), as condiçôes de produção e a leitura.

Como delineia o autor, a partir da hermenêutica, a ciência da interpretação, o texto literário passa a ser interpretado como um todo constituído interna e externamente. $\mathrm{E}$ uma das manifestaçôes dessa corrente interpretativa foi, justamente, a Estética ou Teoria da recepção.

Jauss (1979), a partir da teoria da recepção, aborda sobre a práxis ou experiência estética considerando suas manifestaçôes histórico-sociológicas e orientando-se a partir de três funçôes fundamentais: a Poiesis, a Aisthesis e a Katharsis, que ele denomina, respectivamente, como as atividades produtiva, receptiva e comunicativa da obra.

A poiesis se dá no ato da produção. Com base aristotélica, diz da "faculdade poética” do autor, que gera uma dupla produção, a da obra e a do prazer ante a sua realização.

A aisthesis se estabelece a partir da experiência estética receptiva que possibilita tanto a confirmação do horizonte de expectativas do leitor quanto à transformação de sua realidade interna e/ou externa a partir do encontro com o texto: "A experiência da aisthesis pode, por fim, se incluir no processo de uma formação estética da identidade, quando o leitor faz a sua atividade estética ser acompanhada pela reflexão sobre seu próprio devir [...]" (JAUSS, 1979, p. 82).

A katharsis compreende a comunicação, que se concretiza pela relação entre texto e leitor. A arte literária, a partir dessa experiência, torna-se instância de mediação no direcionamento de ações do receptor, ganhando dessa perspectiva função social. A experiência estética passa de subjetiva à intersubjetiva, ou seja, diz não só do eu autor ou leitor, mas da interação entre suas identidades intercomunicadas.

Para o autor, é necessário estabelecer a comunicação entre dois polos da ligação texto e leitor. O primeiro polo refere-se ao efeito produzido pelo texto e o segundo à recepção feita pelo destinatário, o que constitui o que ele chama de sentido como duplo horizonte: o interno - literário - e o mundivivencial - o que o leitor carrega. Observamos que esse duplo horizonte é propulsor de construções e reconstruçôes significativas em torno do sistema comunicativo - autor-texto-leitor. 
Como observamos, a Estética da recepção reconfigurou o sistema literário, inserindo em sua base a dimensão do leitor. Nesse processo, a comunicação é peça chave para a troca de significaçôes experimentadas pelos sujeitos da produção, autor, leitor e o objeto, o texto.

Ao tratar sobre o lugar do leitor dentro dos estudos literários, Compagnon (1999) observa a existência de uma concepção dicotomizada, que pode ir de uma completa desconsideração da presença do receptor até à sua supervalorização. $\mathrm{O}$ autor procura uma alternativa para a dicotomia, uma terceira via, entendendo a leitura como um processo ambíguo, que se encontra entre dois extremos: entre a autoridade do autor e da obra e seu possível discurso objetivo e a autoridade do leitor e seu discurso subjetivo. A leitura encontra-se, pois, em um entre-lugar.

Eni Orlandi (2006), do plano da análise do discurso, nos ajuda a refletir criticamente sobre a leitura. A autora, de início, reconhece a polissemia da noção de leitura, observando as diversas acepçóes que podem ser atribuídas a ela, podendo ter um significado mais amplo, quando entendida como uma forma de atribuir sentidos, até uma significação mais restritiva, vinculada à escolaridade e à alfabetização. São várias as noçôes, de diversas perspectivas, mas nos orientando a partir dos pressupostos de Orlandi, entendemos que a leitura pode ser compreendida a partir da ideia de interpretação e compreensão. Partimos de alguns pontos de reflexão desenvolvidos pela autora: primeiro, o de que tanto a escrita quanto a leitura compóem um processo de instauração de sentidos; segundo, tanto os sujeitos quanto os sentidos atribuídos por eles são condicionados histórica e ideologicamente, uma vez que não só o sujeito leitor, como aponta a estudiosa, mas também o sujeito produtor têm suas especificidades históricas e vivem em determinados contextos.

Para a autora, as relaçôes sociais, históricas e ideológicas indicam a dinâmica do processo de leitura, elas integram, juntamente com outros componentes, os sujeitos autor e leitor, os diferentes tipos de discurso.

Também Terry Eagleton (2006, p. 126) afirma que "Todos os leitores estáo social e historicamente situados, e a maneira pela qual interpretam as obras literárias será profundamente condicionada por esse fato." Desse modo, o leitor e também produtor, que se coloca a partir de um entre-lugar (BHABHA, 2011) cultural, que é perpassado e entrecortado por relaçóes de poder, de histórias, de momentos e significações, vai, justamente, movimentar um 
discurso literário que não é inocente, que, perigosamente, se constrói em meio a tensôes. Assim, "tendemos a falar hoje de literaturas em condições histórica e socialmente específicas de produção e recepção". (BEVERLEY, 1997, p. 12).

A partir de tais pressupostos, reconhecemos que a leitura é uma atividade profundamente importante na construção histórica, social e cultural dos indivíduos. Ler é atribuir sentidos, formar significados em relação às nossas dinâmicas de vida, com construçóes subjetivas e com o contexto em que nos situamos. Destarte, consideramos necessário, a partir de uma perspectiva racial e de gênero, que orienta, em grande escala, a produção literária das escritoras estudadas, refletir sobre a importância do ato de ler na construção e reconstrução de nossas relações intersubjetivas, que passam pelo eu e também pelo outro.

Nessa linha de reflexão sobre a recepção como fator integrante do circuito de produção e circulação literárias, consideramos pertinente também fazer uma breve análise dos textos das escritoras, como forma de recepcioná-los. Para nos ajudar a direcionar o nosso olhar sobre produçóes literárias das escritoras pesquisadas é necessário, antes, compreendermos, como se construiu, historicamente, a recepção direcionada a textos pautados por uma perspectiva da afro-brasilidade. É com Cuti (2002) que iremos constatar que, primeiramente, no estabelecimento da relação entre o leitor e o texto afro-brasileiro, há uma questão que precisa ser pensada: a da identificação.

Em princípio, o autor reconhece que, historicamente, um ideal de brancura orientou essa relação, pois na tradição literária foram predominantemente perpassadas personagens brancas, sendo as personagens negras excluídas ou retratadas de forma figurativa ou estereotipada. Assim: “[...] na relação do público com a obra afro-brasileira surgem questóes que dizem respeito ao posicionamento da sociedade brasileira em face da questáo racial" (CUTI, 2002, p. 12). Portanto, devemos voltar a atenção para o modo como o público se relaciona com a obra, como se vê a partir do texto, se há uma identificação e de que forma se dá, levando em conta fatores históricos, culturais e ideológicos perpetrados em nossa sociedade.

Vemos retratada, ao longo do tempo, na literatura, a imagem do negro necessitado de custódia, de tutela do outro branco. O negro sem condiçáa de se expressar, mas necessitado de alguém que fale por ele. Como resíduo da época escravocrata, os negros foram, por muito tempo, retratados de forma desumanizada, coisificados, tratados e retratados de tal forma no plano da es- 
critura. Compreendemos que uma leitura pode potencializar ou destruir, marcar positivamente ou negativamente a subjetividade dos sujeitos: "O prejuízo psicológico de uma obra literária pode ser arrasador para um leitor desavisado, ingênuo, que se emocionará e passará a dar crédito afetivo e efetivo ao que leu." (CUTI, 2010, p. 89)

Maria Anória de Jesus Oliveira, pesquisadora de diversos temas voltados para as relaçóes étnico-raciais, especialmente da Literatura infanto-juvenil afro-brasileira e moçambicana, parte, em sua pesquisa de doutorado, entre outras inquietaçôes, da reflexão quanto à ausência e/ou inferiorização de seres ficcionais negros em produçóes literárias brasileiras, especialmente nas obras infanto-juvenis, apontando para a necessidade de atualização desse repertório:

É importante salientar a relevância de os personagens negros aparecerem em diversificados papéis, de antagonistas, protagonistas e não só secundários. Desse modo, as crianças e jovens, tanto negras quanto brancas, além dos demais segmentos étnico-raciais, terão maiores possibilidades de se identificar e redimensionar olhares sobre o espaço social, através da leitura literária. (OLIVEIRA, 2010, p. 53)

Assim, partindo de uma literatura basilar, que é a infanto-juvenil, estendendo-se às demais, foi necessário reescrever o (a) negro (a), atribuindo à sua imagem uma dignidade. As autoras, aqui estudadas, desconstroem a degradação feita historicamente sobre a imagem do negro e da negra, forjam seus próprios caminhos, libertários de uma dependência. É o que encontramos nos textos poéticos e prosaicos das escritoras sujeitos da pesquisa. As autoras fazem leituras de construçóes culturais, do passado histórico, de paradigmas raciais e de gênero, inclusive, retratados em textos literários, ressignificando-os, pondo no centro de seus discursos sujeitos sociais antes estigmatizados, a partir de outros referenciais.

Em "A benção meu pai", conto dos Cadernos Negros', volume 34, Fátima Trinchão (2011) traz para a trama elementos da cultura e tradição afro-

5 Antologia criada, em 1978, fase de redemocratização do Brasil, por escritores negros que se uniram no intuito de dividir os custos da publicação e visibilizar a literatura negra. Desde então é lançada todos os anos, alternando entre poemas e contos.... 
-brasileira e africana, assim como situações cotidianas vivenciadas por muitos negros no Brasil.

O conto gira em torno de uma família negra, mais especificamente da relação entre um pai e filho, residentes em Salvador - BA. Algo que aparece muito forte é a transmissão de conhecimentos sobre a história e cultura africana e afro-brasileira de pai para filho, pois é feita a alusão, em vários momentos da narrativa, a fatos históricos muitas vezes ocultados ou tratados de forma superficial pela história oficial, inclusive, a perpassada em ambientes educacionais, no geral.

A autora utiliza acontecimentos históricos que confirmam a grande participação dos negros na construção do Brasil, mesmo às duras penas. Evidencia, assim, o caráter ativo do negro, sua resistência à escravidão. Ainda o sujeito negro (a) é retratado como aquele que busca o conhecimento, gosta de ler, de estudar, algo que é visto de forma contrária em nossa sociedade, uma vez que, no geral, sua imagem é associada à ignorância e indiferença à aquisição de conhecimento.

O conto tem um forte cunho ancestral, pois, em vários momentos, as personagens se reportam à África e seus elementos culturais e religiosos, como, por exemplo, a referência a Oxalá, deus da criação, a quem é atribuído o poder de abençoar. Tal referência é retomada em vários momentos na narrativa, pois a personagem do pai frisa bastante a importância do costume dos mais novos tomarem a benção aos mais velhos, expressando a passagem da tradição, entre geraçóes. A ênfase na lembrança das origens africanas e da história dos negros no Brasil é dada em vários momentos e mostra a preocupação da escritora em tornar viva e não esquecida nossa história e raízes.

As escritoras pesquisadas formam, com seus escritos, uma vasta fonte de discussão de questóes sociopolíticas e culturais, como a da afirmação do negro e das raízes afrodescendentes, a luta e a resistência da mulher, o canto à liberdade e o desafio aos sistemas de poder estabelecidos. Uma vez que concebemos a leitura como uma prática de potente intervenção social, é por esse diferencial dos textos das escritoras, que se encontra a importância de lê-los e recepcioná-los.

É no movimento que abrange escrita e subjetividade das escritoras e a leitura, por parte de um leitor crítico, que pretendemos debruçar o olhar para formas de ser e representar que vão contra "processos de modelagem" sobre 
os quais abordam Guattari e Rolnik (1996). A partir dos postulados destes autores, consideramos pertinente refletir sobre os processos de homogeneização a que os indivíduos são submetidos, processos esses de subalternização e infantilização.

Nessa perspectiva, atentamos para o modo como as escritoras recusam/ subvertem modelagens hegemônicas e suas formas de opressão em um movimento de devir, de economia do desejo, operando novos processos de formação. Esse movimento de subversão e devir é envolvido por um deslocamento na forma de ser, fazer e estar, já que, como afirmam Gomes e Zolin (2011, p. 7) "o deslocamento é uma marca da escritora brasileira tanto como tema quanto como estratégia de sobrevivência no mercado editorial”. Esses deslocamentos na escrita, na forma de representação, na maneira de ser, nos modos de produzir configuram-se como práticas de resistência à forma como foram deslocadas por dispositivos mercadológicos, canônicos, excludentes das práticas do direito ao lugar de escrita; da possibilidade de serem conhecidas e lidas.

Nessa direção, observamos como elas deslocam lugares de falas estereotipados e como recusam um consciente formatado, modelado, verbalizando o discurso próprio e não o do alheio, uma vez que a apropriação da escrita pelas mulheres negras perpassa, justamente, pela produção da subjetividade, pela necessidade de afirmação enquanto sujeito. É o que visualizamos no poema "Autoestima", de Jocelia Fonseca:

A beleza que nos conduz para a luta

É a mesma que nos mantém no dia a dia

Como feras de presas saudáveis

A agarrar o que nos é de direito.

Tomemos o lugar que é nosso

Que nos tomaram sem licença.

Minha licença agora,

Será apenas por uma questáo

de educação ancestral.

Mas olharei na tua cara,

através dos teus olhos 
e direi:

Não mais conduzirás meus anseios,

Meu amor, minha sorte!

Sou dona dos meus belos cachos,

Da minha pele cor de noite

E do meu nariz.

Esse nariz que não passa nos moldes que

Inventaram padrão.

Vá se chatear você!

Quando me vir passar com um belo sorriso

Largo

Nos meus lábios largos.

Senhores opressores e preconceituosos da

minha vida.

Vá você se inferiorizar!

Vá você se deprimir!

Porque eu vou passar as ruas como se

Fossem passarelas,

A receber esta rainha negra!

(FONSECA, 2012, p. 71)

Este poema de autoafirmação da mulher negra é considerado pela escritora Jocelia Fonseca o seu hino. O eu poético expressa uma forte subjetividade negra e feminina, longe de padróes eurocêntricos estabelecidos. A beleza da mulher negra é trabalhada com riqueza de detalhes, desconstruindo estereótipos depreciativos. $\mathrm{O}$ eu poético se dirige a dois tipos de receptores: um dentro de seu horizonte de expectativas, tocado pelas mesmas marcas identitárias, e o outro diferente, ao qual o diálogo se dirige em um tom de desabafo, questionamento e mudança de paradigmas.

Como elucida Cuti (2002), a escrita marcada pela etnicidade negra permite uma relação de intersubjetividade entre escritor (a) e leitor (a) negros (as), uma vez que estes se reconhecem em sua singularidade. A leitura dessa forma tem um poder de reparação, pois proporciona ao indivíduo leitor um voltar-se para sua interioridade e o seu reconhecimento como sujeito, contribui com a restauração positiva da autoimagem, o que, consequentemente, re- 
verbera na autoestima do mesmo. Como aponta o autor, a literatura, marcada por esse prisma, se abre a outro referencial identitário, permite a formação um leitor ideal negro. Assim, surgem modos de escrita que se dirigem diretamente, como afirma o autor, "aos seus". No poema de Fonseca, pudemos observar que além de dialogar com "os seus", a voz poética também se dirige ao outro que exclui, categoriza, inferioriza indivíduos com os mesmos traços fenotípicos retratados pela autora e que expressam uma imagem negra. Imagem essa que é ressignificada pelo viés positivo e auto confirmado, tanto para tocar o seu "igual", quanto para dizer de sua independência a padróes estabelecidos pelo outro considerado referencial. Com isso, demonstra-se que:

Há um leitor virtual inscrito no texto. Um leitor que é construído no próprio ato da escrita. Em termos do que denominamos "formaçôes imaginárias" em análise de discurso, trata-se aqui do leitor imaginário, aquele que o autor imagina (destina) para seu texto e para quem ele se dirige. Tanto pode ser um seu "cúmplice” quanto um seu "adversário”. (ORLANDI, 2006, p. 9)

Nesse sentido, quando o leitor real, aquele que lê o texto, se depara com este, já encontra incutido aí um leitor "prévio", o virtual, aquele projetado pelo (a) autor (a). Esse encontro, para Orlandi, é o primeiro fundamento para o processo da interaçáo da leitura, um confronto entre leitor virtual e leitor real. Para a autora, o leitor não interage com o texto (relação sujeito/objeto), mas com outros sujeitos (leitor virtual, autor, etc.). Nós não nos orientamos tão somente por esta última afirmação de Orlandi, uma vez que reconhecemos também a interação entre leitor e texto, mas a consideramos como mais uma perspectiva que alarga nossa concepção sobre o processo da leitura, sobre as condiçốes de produção de modos de ler.

O horizonte de expectativas - referente às crenças e leituras prévias do mundo -, pode ser modificado no decorrer da leitura, o que é um ponto chave para a desestruturação de sistemas de dominação e colonialidade ainda existentes, mesmo de forma residual, em nossa sociedade. Então o leitor que traz uma bagagem preconceituosa, unilateral, pode, ao se deparar com os textos das escritoras, passar por um processo de modificação que contribua para a abertura ao diferente. 
Carlos Magno Gomes (2010) aponta como a leitura literária ganha relevância se trabalhada de forma interdisciplinar, ao se apropriar de duas formas de interpretação, a estética e a cultural. Dentro dessa acepção, a leitura tem implicaçooes no processo de formação cidadã do leitor, incluindo enfoques culturais, sem, no entanto, excluir as abordagens estético-literárias do texto. Lida dessa maneira:

[...] a literatura assume um papel fundamental, pois, a partir do contato com o texto, o gosto pela leitura pode ser despertado como uma prática de reflexão social. Assim, o convite à reflexão social pode ser uma das saídas para associar leitura, prazer e formação da consciência crítica do leitor. Nesse sentido, as ideias defendidas aqui se vinculam a uma prática de leitura na qual os elementos estéticos sejam lidos como ideológicos. (GOMES, 2010, p. 28)

Corroborando com o autor, essa modalidade de leitura, se desenvolvida em nossos contextos sociais, teria efeitos transformadores sobre os leitores, ao provocar nestes o pensamento crítico sobre formaçóes subjetivas, desembocando em uma postura politizada por parte dos sujeitos. "Nesta proposta, tanto a memória cultural como a recepção do leitor crítico são abordados como partes do processo de leitura”. (GOMES, 2010, p. 31)

É essa leitura potencializada que Stuart Hall (2003) trata a partir do modelo de codificação/decodificação. Decodificar implica ler de forma plural. Permite-nos ressignificar algo que já foi pré-significado com pretensóes de fixação; compreende ler não somente por uma via dada, mas por outras perspectivas, o que nos leva a romper com o hegemônico, o instituído. Como indica o teórico, o texto não é apenas um conjunto semiótico a ser decodificado de qualquer maneira, pois: "[...] implica uma questão de poder. Alguém tem de controlar os meios de significar o mundo. Muitas pessoas lá fora não têm outra forma de conhecer o mundo a não ser através do significado que se comunica a elas" (HALL, 2003, p. 368).

O modelo de codificação/decodificação nos ajuda a refletir sobre quais significados estão nos comunicando e como os lemos. Como afirma Hall (2003, p. 369), “a ideologia é uma tentativa de fixar o significado", e, para tanto, necessita do recurso que é a linguagem. Portanto, é importante a iden- 
tificação e tensão de marcas de poder presentes nos textos e o desmonte dos sentidos pré-fixados. Isso nos ajuda a pensar em qual noção de leitura e de recepção queremos desenvolver.

Hall propóe a passagem da leitura superficial apenas codificada, para a leitura reflexiva e ativa, que decodifica. Nesse processo, o legitimado é deslocado, não destruído. Destarte, nesse processo de leitura potencializada, a literatura feminina negra pode ser utilizada como instrumento de reparação, visto que constrói, tomando como foco o que lemos, uma identidade negra feminina, baseada na positividade, na valorização da cultura ancestral e de um corpo que é e se quer negro, o que é crucial no processo de formação do individuo leitor.

Também podemos encontrar, na literatura das escritoras estudadas, a construçấo de um discurso que insere a mulher no mundo como sujeito ativo crítico-reflexivo, que ajuda a (des) construir a si mesmo e ao seu espaço social, que tensiona as relaçóes de gênero. É o que constatamos na prosa e na poética de Rita Santana, visto que, para além de uma experimentação estética do prazer, seus textos produzem uma experimentação que toca e perpassa o cotidiano do sujeito leitor e seus modos de vida.

Rita Santana traz em sua poética o registro de uma feminilidade ambivalente, pois evidencia, ao mesmo tempo, a condição de passividade perpetrada como natural a nós mulheres e, ao mesmo tempo, a ousadia da fêmea, a possibilidade de tornar-se outra mulher. O poema "Eva" ilustra bem esse processo:

Sou tua mulher.

Aceito-te assim, feito macho.

Oculto de ti minha saliva, meu sangue, minha língua, meu suor,

Ofereço-te cachos de uvas verdes,

Apresento-me limpa para o deleite dos teus lábios secos.

Diante dos teus brados, curvo-me, pacata, saciada,

Se molhada, ponho barro entre as pernas

E sob tuas linhas, apenas aguardo.

Masco ervas aromáticas,

Pois meu hálito acordaria tua brandura.

Engulo palavras, pensares, e amarro meus gestos com pulseiras. Assim, meu pulsar se extingue com o tempo. 
Só devo dizer-te que um dia:

Hei de oferecer-te o fruto inteiro, intacto, com talo e tudo,

Hei de fazer-te um deus, inda que de parreiras,

Hei de dar-te passos tortos, andares livres,

Hei de perecer feito fêmea, longe das divindades,

Hei de mostrar-te como eu sou, sem receios,

Com meus fartos seios murchos de espera,

Murchos das grades

À noite, acordo em busca de silêncios, sapiências,

Vasculho minha arca perdida no quarto dos fundos,

Mas não encontro conforto para os meus calares.

(SANTANA, 2006, p. 58)

O título do poema, já nos leva a associar a figura dessa mulher trabalhada no texto à mulher considerada a primeira da humanidade, mas que traz, dentro de uma construção cultural, a herança da subserviência ao homem, posto que teria sido criada a partir da costela de um. É uma construção histórica sobre a imagem da mulher. Mulher que precisa reprimir seus impulsos, seus desejos, sua voz, que somente deve agir sob a tutela e a ordem da figura masculina, como evidenciam os versos destacados: "Sou tua mulher. Aceito-te assim, feito macho".[...]; "Diante dos teus brados, curvo-me, pacata, saciada, [..]"; "E sob tuas linhas, apenas aguardo"; "Engulo palavras, pensares, e amarro meus gestos com pulseiras". Observamos que a poeta expressa, de forma lírica, metafórica a imagem de subserviência, silenciamento e repressão atribuída historicamente à mulher, e, ao mesmo tempo, desmonta-a, aludindo ao desejo de torna-se outra: "Só devo dizer-te que um dia: "[...]Hei de dar-te passos tortos, andares livres, [...] Hei de mostrar-te como eu sou, sem receios" ; “[...] não encontro conforto para os meus calares". Os versos exprimem um incômodo com a formatação desse eu lírico feminino e, em um movimento de devir, dá indícios da possibilidade de tornar-se outra que não se apassiva diante da presença do homem, mas que, ao buscar romper com um calar, com um silêncio perpetrado há tempos, pode então voltar a viver e de forma livre.

A poesia de Santana queima, arde, mas alivia, ecoa virilidade e a brutalidade das relaçôes áridas, doídas. É uma imensidão de sensibilidade e lirismo. 
São versos que atingem a profundidade do nosso íntimo, toca o útero, as entranhas, a mulher por inteiro. São versos viscerais e intensos.

Rita Santana, em entrevista ${ }^{6}$, deu ênfase à importância de se trabalhar a subjetividade da mulher, especialmente a negra. Para a escritora, é primordial fazer o exercício sofrido e cotidiano de reconstrução dessa subjetividade, como diz: "a todo tempo agredida, estuprada, violentada, também simbolicamente" (SANTANA, 2014). Como afirmou a autora: "O verbo vira arma!" (SANTANA, 2014) e arma de enfrentamento contra o machismo, o sexismo, o racismo. Em "Entrega" também a voz lírica questiona a passividade e o silenciamento imputado a nós mulheres, e traz o conflito da subserviência e da negação desse lugar:

Afundo os meus navios

Olhando o quanto sou fogueira de velas muitas.

Marca na testa é sinal de deusa Musa.

Limpo o chão da casa dos meus súditos,

Colho as ervas finas do dia,

Ancoro repolhos no molho branco,

E digo não, quando quero.

Ademais, quem disse que eu presto?

Protesto demais pra uma coisa fêmea,

Memória me diz:

Lugar de mulher é no silêncio,

Tormentas, é homem quem sofre.

Estou em cada comboio de gente que busca alento em lugar,

$[\ldots]$

Vontade sinto de cortar caminhos

Por onde passa esse rio vermelho.

Cansei-me, há muito, de ser,

Só trago continuísmos de lesmas.

Recuso-me a dormir calada,

Alada, voaria até o sol para derreter-me as asas.

(SANTANA, 2006, p. 55)

6 Concedida em 11 de abril de 2014 para fins de participação na pesquisa de mestrado. Algumas falas da escritora são trazidas ao longo do texto, identificadas pela referência (SANTANA, 2014). 
Podemos observar nos textos de Santana, entre tantas outras questóes, a subjetividade latente da mulher que vive o conflito de uma sociedade, de uma formação cultural que lhe negou o direito à voz, à expressividade da autonomia. Por isso, vemos a retratação da mulher que, mesmo em meio a esse contexto, pensa, deseja falar, exprimir sua voz e se arma de palavras. Também observamos a retratação de mulheres fortes, a evidência de uma identidade negra, pois a escritora, várias vezes, faz menção a um corpo de mulher negra que traz em si veias ancestrais de resistência, que se figura em espaços passados e realidades presentes.

A autora possui uma preocupação com o trabalho artístico no livro, de modo que chame a atençáo do público leitor e lhe desperte a sensibilidade. A autora trabalha com um apuro das palavras e expressóes que conferem intensa poeticidade aos textos. Santana desnuda em cada verso um eu lírico feminino que se quer prenhe de vida, de amor, de liberdade.

O seu último livro publicado Alforrias é composto por 28 poemas que exprimem inquietaçóes, angústias, desejos, sublimaçóes com uma intensa carga de lirismo e dramaticidade. Como o próprio título indica, o livro nos abre a caminhos de libertação do eu, da fala, dos sentimentos e cometimentos que nos cerceiam e nos fazem morrer simbolicamente e cotidianamente.

Sobre a capa do seu livro Alforrias que traz a imagem de Frida Kahlo ${ }^{7}$, Rita Santana declara:

É essa mulher que também me seduz. É uma paixão. É um parâmetro de artista, de mulher que enfrenta e suporta essa carga que a vida lhe deu, física, e transforma tudo isso. Acho que tem tudo a ver com muitas mulheres, essa coisa da superaçáo constante. Você tem que enfrentar esses espinhos e esses pregos e essa coluna partida. As nossas colunas estão partidas, nós nascemos com as colunas partidas e temos que segurá-las em pé pra enfrentar todas as adversidades sociais. (SANTANA, 2014)

7 Ícone feminino de superação, Frida Kahlo nasceu em 6 de julho de 1907, em Coyoacán, no México, e teve, desde criança, uma vida marcada por doenças e acidentes, tendo o mais grave, em 1925, partido sua coluna e lhe causado múltiplas fraturas. O que não lhe impediu de ingressar na seara da pintura, tornando-se uma grande artista das artes visuais Além disso, teve uma vida matrimonial conturbada, o que mais uma vez lhe exigiu força e superação. 


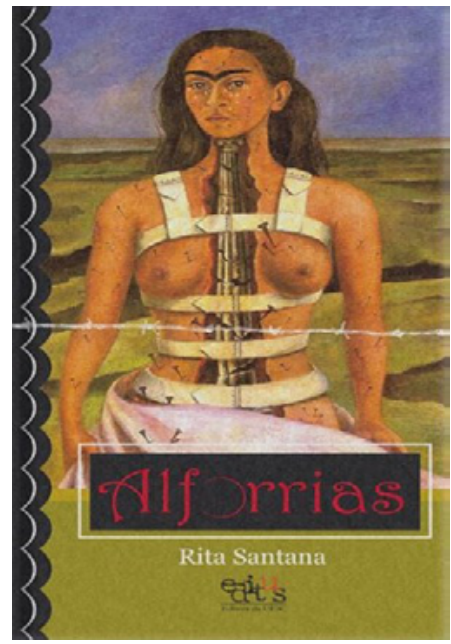

Ilustração 1: "Capa de "Alforrias"

Observamos a riqueza de detalhes da imagem de Frida Kahlo, os pregos em sua carne, a coluna partida. Como pudemos visualizar, a imagem tem uma importância que se alia, intimamente, à escrita da autora. Ambas expressam a nudez de uma alma feminina encravada por opressóes, mas que se quer libertária, exprimem as sinuosidades do ser fêmea, as cruezas de ser mulher, dores, apertos e sufocos causados pelas histórias de vida, pela construção de si na relação com o mundo, com o outro.

Nesse sentido, a ilustração aparece como um chamamento, corroborando com um despertar da sensibilidade do público leitor que diante da imagem de Frida Kahlo, mulher forte e que inspira, começa um processo de pré-leitura da obra, já que a figura é indiciária de um conteúdo do livro, também tecido por uma escrita forte.

Também um desenho de pássaros surge de forma singela no meio do livro, e retrata, simbolicamente, a possibilidade de voo e de liberdade das cercas e arames farpados que nos prendem, que embotam nossa subjetividade.

Pudemos observar, a partir da produção literária das quatro escritoras pesquisadas, que a produção de suas subjetividades, por vezes, imbrica-se com seus textos. A construção ideológica é permeada por esse viés. Desse modo, é imprescindível pensar de que forma estamos nos produzindo e como a leitura ajuda nesse processo. 
A literatura construída por mulheres, especialmente por negras, é uma de suas melhores formas de resistência, de devir, pois atua na quebra do emudecimento de suas vozes, evoca a valorização do ser feminino, especialmente marcado pela negritude e revoluciona o macro sistema literário e social. Guattari e Rolnik (1996) ao trabalharem com a questão da subjetividade de grupos subalternizados, como mulheres, negros, entre outros, nos aponta, entre outras considerações que: "Ha um devir negro da pintura, um devir negro da musica, assim como se poderia dizer que ha um devir minoritário da literatura - recusada inscrição da literatura nas formas dominantes". (GUATTARI; ROLNIK, 1996, p. 74)

O devir resulta da provocação feita pela "voz" do texto que faz eco no interior do leitor. Isso caracteriza uma interlocução que se dirige diretamente a quem está lendo. $\mathrm{O}$ ato de ler contribui, assim, no processo de construção e reconstrução do eu, no questionamento de uma imagem formatada. É uma nova imagem da mulher negra, do seu corpo e sua sexualidade, e de relaçóes emotivas que encontramos em "Vou me embora pra Oshogbo" de Mel Adún:

\author{
Vou-me embora pra Oshogbo \\ Lá sou filha de rainha \\ Me deitarei só com quem eu quiser \\ Só se for vontade minha \\ Vou-me embora pra Oshogbo \\ Vou-me embora pra Oshogbo \\ lá vou ser feliz \\ não terei que me relacionar \\ com homens de qualquer lugar \\ espanha, estados unidos, paris \\ Só se for vontade minha \\ $[\ldots]$ \\ (ADÙN, 2014, p. 154)
}

O poema de Mel Adún traz à tona uma mulher autônoma, dona de seu corpo, de seu desejo, de seu querer. Antes sujeitada ao domínio do homem branco, mostra-se por outra perspectiva identitária, que expressa a liberdade de escolha para ser o que quiser, para sentir e não somente dá o prazer e a 
quem quiser. Assim, a apropriação da arte literária pelas mulheres negras permite também a passagem das mesmas de objetos a sujeitos. Esse movimento de quebra de estereótipos e sujeições é importante, uma vez que: "A ficção ainda se ancora nas imagens de um passado escravo, em que a mulher negra era considerada só como um corpo que cumpria as funções de força de trabalho, de um corpo-procriação de novos corpos para serem escravizados e/ou de um corpo-objeto de prazer do macho senhor" (EVARISTO, 2009, p. 23).

Ao transgredir com imagens perpassadas historicamente, a escrita feminina negra evidencia sua qualidade ativa e a reconstrução de um eu feminino negro que se tece em meio ao devir. Demonstra a capacidade de se reinventar, de repensar a produção desigual das relaçôes sociais, raciais e de gênero e, consequentemente, culturais e políticas desses sujeitos, em relação aos grupos dominantes. Esses sujeitos, pois, atuam pelo eixo do devir, que se expressa de diversas formas, entre elas através da escrita, da literatura. Destarte:

A apropriação discursiva, pela maioria destas escritoras, revela a percepção do perigo da fala, ativa este perigo na escrita, sangrando palavras e engendrando um contradiscurso. Engendrando uma outra percepçáo de si, que se faz no ato de escrever, no ato de relatar sobre si. A escrita/fala, portanto, matando sujeito e fazendo-o ressurgir. (MOREIRA, 2012, p. 10)

O discurso crítico das escritoras se tece na formação de uma textualidade da qual emerge outra percepção delas mesmas e de tantas outras mulheres que são tocadas no cotidiano por marcadores socioculturais do gênero e da raça. É através da linguagem que elas ressignificam o mundo, comunicando outras formas de vida, outros modos de ser. Já afirmara Eagleton (2006), a partir dos pressupostos de Husserl, que nossas experiências de vida se processam por meio da linguagem, e não ao contrário, em uma linguagem sem significados. Pois, "imaginar uma linguagem é imaginar toda uma forma de vida social" (EAGLETON, 2006, p. 93).

É, pois, pela imaginação e recriação de libertárias e renovadas formas de vida social, que as escritoras recusam modelagens e criam processos de singularização, em um movimento de autonomia em forma de linguagem. Assim, a mulher de que não se fala, ou se quando fala é de forma estereotipada, adquire 
voz e faz emergir sua alteridade por meio da arte, do texto, lançando novas representações sobre si própria. Portanto, à medida que desconstroem papéis e funçôes, estabelecidos historicamente à sua volta, e desmascaram o que é legitimado, geram uma nova percepção de si mesmas e a construção de outra identidade, que mostra essa mulher, politicamente esclarecida, que busca reverter uma ordem pré-estabelecida, fazendo reverberar esse movimento também na subjetividade daquele (a) que lê.

A literatura feita por uma mulher negra, que se coloca como sujeito do discurso, nos mostra como a apropriação do texto literário tem contribuído para desestabilizar, deslocar representaçóes, normatizaçóes e formas naturalizadas de ser, estar e fazer. "Nesse jogo, de (re) constituição de si, a linguagem figura como potência de asfixiar, bem como de oxigenar, de válvula de escape para outra vida" (MOREIRA, 2012, p. 10).

A escrita de mulheres negras é, por essa via, um artefato, um meio de reconhecimento e de ressignificação das mesmas, dentro de um contexto sociocultural, e também literário, que por muito tempo destituiu seu lugar de fala, relegou sua presença, ou quando a considerou foi de forma estereotipada, negativa. Entendendo o símbolo como uma forma de tipificar, representar, ou lembrar algo, por meio de atributos comparáveis e associativos em fatos ou pensamento (TURNER, 2005, p.49), a escrita de mulheres negras, desse modo, conjectura-se como um símbolo de representação da presença negra feminina, fazendo lembrar sua resistência e atividade produtiva.

Apesar das restriçóes a que estiveram e têm estado sujeitas, as mulheres, como as escritoras negras baianas trazidas nesse texto, buscam reverter uma ordem, falam de um lugar e longe do discurso de vitimização, insurgem como força motriz para balançar com estruturas socioculturais e políticas "engessadas".

Pensando no simbólico operado por Deleuze (2006), a escrita de mulheres seria como um elemento simbólico que trabalha com o real e o imaginário, ou seja, com a exclusão histórica dessas mulheres, com suas alteridades, suas qualidades negadas, sua imagem, pondo em relação com a arte, com o campo imaginário, ficcional para retratar, através de personagens, eu poéticos e histórias, o que essas mulheres têm a contribuir, suas potencialidades, como forma de intervenção cultural. A escrita é, assim, um instrumento usado pelas escritoras na desconstrução e construção de olhares, a partir da perspectiva do sujeito do discurso mulher negra. 
Os textos das escritoras estudadas se constituem, então, como uma ferramenta crítica, política, sendo o lócus onde se constroem novos sentidos, novos discursos sobre mulheres (negras), tecendo, assim, relações de poder, desmontando estereótipos, construindo novos modos de ver e reconhecer a mulher negra e suas relações com o mundo.

Portanto, a literatura das escritoras negras baianas pesquisadas potencializa a leitura ao contribuir nos processos de construção, desconstrução e reconstrução subjetivos, ao trazer, pelo elemento estético da linguagem, questôes históricas, ideológicas e socioculturais de formas ressignificadas. Assim, através de tais práticas de leitura, podemos desconstruir processos de colonialidade ainda sentidos em nosso cotidiano, instigando, com a tradução disso em seus textos poéticos, outras releituras, outros leitores, sujeitos. Por isso a importância do fomento à leitura e recepção dessa literatura, de forma crítica, aliada à construção subjetiva, cultural, política e social dos sujeitos produtores e leitores.

\section{Referências}

ADÚN, Mel. Paradoxo. Vou-me embora para Oshogbo. In: ADÚN, Guellwaar; ADÚN, Mel; RATTS, Alex. (Orgs.) Ogum's Toques Negros: Coletânea poética. Salvador: Ed. Ogum’s Toques Negros, 2014, p. 154.

BEVERLEY, John. "Por Lacan": da Literatura aos Estudos Culturais. In: Travessia - Revista de Literatura. No 29/30, Florianópolis: UFSC, ago. 1994/ jul.1997, p. 11 a 42.

BHABHA, Homi. O entrelugar das culturas. In: $O$ bazar global e o clube dos cavalheiros ingleses. Org. Eduardo Coutinho. Rio de Janeiro: Rocco, 2011.

COMPAGNON, Antoine. O demônio da teoria: literatura e senso comum. Tradução de Cleonice Paes Barreto Mourão e Consuelo Fortes Santiago. Belo Horizonte: Ed. UFMG, 1999.

CUTI, Luiz Silva. O leitor e o texto afro-brasileiro. In: FIQUEIREDO, Maria do Carmo Lana; FONSECA, Maria Nazareth Soares (org). Poéticas afro-brasileiras. Belo Horizonte: Editora PUC Minas, Mazza Ediçóes, 2002. p. 19-36.

CUTI, Luiz Silva. Literatura Negro-Brasileira. São Paulo: Selo Negro, 2010.

DELEUZE, Gilles. Em que se pode reconhecer o Estruturalismo. In: A ilha deserta e outros textos. São Paulo, 2. Reimp. : Iluminuras, 2006, p. 221-247. 
EAGLETON, Terry. O que é Literatura? In: Teoria da literatura: uma introdução. 6a. Ed. São Paulo: Martins Fontes, 2006, p. 1-24.

EVARISTO, Conceição. Literatura Negra: uma poética da nossa afro-brasilidade. In: Scripta. Belo Horizonte, v. 13, n. 25, 2009, p. 17-31.

FONSECA, Jocelia. Autoestima. In: Importuno Poético. Ediçóes Revoluo: Salvador, 2012, p. 71.

GOMES, Carlos Magno. Leitura e estudos culturais. In: Revista Brasileira de Literatura Comparada, n.16, 2010, p. 25-44.

GOMES, Carlos Magno; ZOLIN, Lúcia Osana. (Orgs.) Deslocamentos da escritora brasileira. Maringá: Eduem, 2011.

GUATTARI, Felix; ROLNIK, Suely. Subjetividade e história. In. Micropolitica: Cartografais do desejo. $4^{\mathrm{a}}$ ed. Petropolis: vozes, 1996.

HALL, Stuart. Reflexões sobre o modelo de codificação/decodificação: uma entrevista com Stuart Hall. In: Da diáspora - identidades e mediaçóes culturais . Liv Sovik. (Org.) Trad. Adelaide La Guardiã Resende (et al). Belo Horizonte: Editora UFMG; Brasília: Representação da UNESCO no Brasil, 2003, p. 353-386.

JAUSS, Hans Robert. A estética da recepção: colocações gerais. In: JAUSS, Hans Robert; LIMA, Luiz Costa. (Orgs.) A literatura e o leitor: textos da estética da recepção. Trad. Luiz Costa Lima. Rio de Janeiro: Paz e Terra, 1979, p. 43 - 62.

LENHARDT, Jacques. Literatura: uma entrada na história. In: SILVA, Vera Maria Tietzmann; TURCHI, Zaira Maria (Orgs.). Leitor formado, leitor em formação: leitura literária em questão. São Paulo: Cultura Acadêmica, Assis, São Paulo: ANEP, 2006, p. 13 - 24.

MOREIRA, Jailma dos Santos Pedreira. Reescrita de si: produções de escritoras subalternizadas. In: Anais Eletrônicos do IV Seminário Nacional Literatura e Cultura. São Cristóvão/SE: GELIC/UFS, 2012, p.1-12. Disponível em: http://200.17.141.110/senalic/IV_senalic/textos_completos_IVSENALIC/ TEXTO_IV_SENALIC_195.pdf Acesso em 15 de jul. de 2013.

OLIVEIRA, Maria Anória de Jesus. Personagens Negros na Literatura Infanto-juvenil no Brasil e em Moçambique (2000 - 2007): entrelaçadas vozes tecendo negritudes. Tese de Doutorado. João Pessoa: UFPb, 2010.

ORLANDI, Eni Pulcinelli. Discurso e leitura. $7^{\text {a }}$ ed. São Paulo: Cortez, 2006. SANTANA, Rita. Entrega. In: Tratado das veias. (Coleção Selo Letras da Bahia) Salvador: Secretaria da Cultura e turismo, Fundação Cultural do Estado, EGBA, 2006, p. 55. 
SANTANA, Rita. Eva. In: Tratado das veias. (Coleção Selo Letras da Bahia) Salvador: Secretaria da Cultura e turismo, Fundação Cultural do Estado, EGBA, 2006, p. 58.

SANTANA, Rita. Alforrias. Ilhéus: Editus, 2012

TRINCHÃO, Fátima. A benção meu pai. In: BARBOSA, Mário; RIBEIRO, Esmeralda. Cadernos negros: contos afro-brasileiros. Vol. 34. Quilombhoje, São Paulo: 2011, p. 81-88.

TURNER, Victor. Os símbolos no ritual Ndembu. In: Floresta de símbolos-aspectos do ritual Ndembu. Tradução de Gabriel Hilu da Rocha Pinto. Niterói, RJ: EdUFF, 2005. p. 49-81.

\title{
READING, RECEPTION AND CONSTRUCTIONS SIGNIFICANT IN TEXTS BLACK WRITERS
}

\begin{abstract}
The following work reflects on the importance of the subject reader in the sphere of literary production, as from authors as Jauss (1979), Eagleton (2006), Orlandi (2006), among others. Combining the theory to analysis of texts the black writers, Fátima Trinchão, Jocelia Fonseca, Mel Adún and Rita Santana, we observe as reading, per a cultural perspective, here signified by the axes of gender and race, can produce significant effects on the social construction of the subject reader.
\end{abstract}

KEY-WORDS: reading; reception; black women writer.

Recebido em: 31/10/2015

Aprovado em: 20/02/2016 